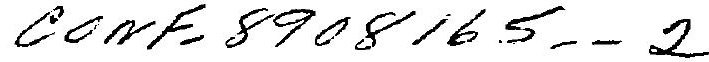

October 1989

To be Published in Nuclear Instruments and Methods

BNL --43097

DE90 003965

\title{
TRACE ELEMENT DISTRIBUTION IN THE RAT CEREBELLUM
}

\author{
W. M. Kwiatek, G. J. Long, J. G. Pounds, \\ K. R. Reuhl, A. L. Hanson, and K. W. Jones \\ Brookhaven National Laboratory \\ Upton, New York, USA
}

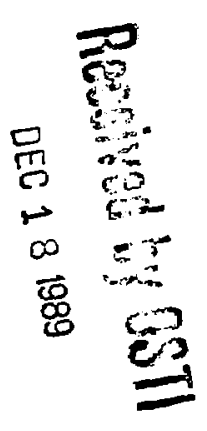

Presented at

5th International Conference on PIXE and Its Analytical Applications

Amsterdam, The Netherlands

August 20-26, 1989

\section{DISCLAIMER}

\begin{abstract}
This report was prepared as an account of work sponsored by an agency of the United States Government. Neither the United States Government nor any agency thereof, nor any of their employees, makes any warranty, express or implied, or assumes any legal liability or responsibility for the accuracy, completeness, or usefulness of any information, apparatus, product, or process disclosed, or represents that its use would not infringe privately owned rights. Reference herein to any specific commercial product, process, or service by trade name, trademark, manufacturer, or otherwise does not necessarily constitute or imply its endorsement, recommendation, or favoring by the United States Government or any agency thereof. The views and opinions of authors expressed herein do not necessarily state or reflect those of the United States Government or any agency thereof.
\end{abstract}

By acceptance of this article, the publisher and/or recipient acknowledges the US Government's right to retain a nonexclusive, royalty-free license in and to any copyright covering this paper. 


\section{TRACE ELEMENT DISTRIBUTION IN THE RAT CEREBELLUM ${ }^{1}$}

W. M. Kwlatek', G. J. Long, J. G. Pounds, K. R. Reuhl. A. L. Hanson, and K. W. Jones

Brookhaven National Laboratory, Upton, New York 11973

\section{ABSTRACT}

Spatial distributions and concentrations of trace elements (TE) in the brain are 1 mportant because IE perform catalytic and structural functions in enzymes which regulate brain function and development. We have investigated the distributions of IE in rat cerebelium. Structures were sectloned and analyzed by the Synchrotron Radiation Induced X-ray Emission (SRIXE) method using the NSLS $x-25$ white-light microprobe facility. Auvantages important for $T E$ analysis of biological specimens wilh $x-r a y$ microscopy include short time of measurement, high brightness and rlux, good spatial resolution, multielemental detection, good sensitivity, and non-destructive irradiation.

Trace elements were measured in thin rat brain sections of 20-micrometers thickness. The analyses were performed on sample vol umes as small as $0.2 \mathrm{nl}$ with Minlmum Detectable Limi ts (MDL) of $50 \mathrm{ppb}$ wet welght for $\mathrm{Fe}, 100 \mathrm{ppb}$ wet welght for $\mathrm{Cu}$, and $\mathrm{Zn}$, and 1 ppm wet welght for Pb. The distribution of IE in the molecular cell layer, granule cell layer and riber tract of rat cerebella was investigated. Both point analyses and two-dimensional semi-quantitative mapping of the TE distribution in a section were used. All analyzed elements were observed in each structure of cerebellum except mercury which was not observed in granule cell layer or fiber tract. This approach permils an exacting correlation of the TE distribution in complex structure with the diet, toxic elements. and runctional status of the animal.

1 Research supported by US DOE Chemical Sciences DI vision Contract NO. DE-ACOZ-76CHOOO16; NIH Blotechnology Research Resource Grant No. P41RRO1838; and NIH Grant No. ESO4C4O. 


\section{SAMPLE PREPARATION}

Two groups with a total number of 8 rats were put on two different diets. The rats from first group were put on American Institute of Nutrition (AIN) diet [3] marked as AIN-7B'M and called here "AIN Diet". This diet is intended for rats growth and maintenarice during the rirst year or $11 \mathrm{re}$. The rats from the other group were put on Ralston Purina Company diet [4] called here "Purina Diet". This diet is designated especially for rats. hamsters and most mouse strains. The Purina Diet is a high-energy and high-protein diet. Table 1 compares the elemental composition of those two diets.

Those rats were fed for 28 days and then sacrificed. For this experiment the selected tissues were removed quickly from the animal and placed on dental wax. Then, with a clean sharp scalpel the tissues were trimmed to provide access to the structures and orlentation required by the experlment. Usually samples were cut down to $<5 \mathrm{~mm}$ in at least one dimension. The trlmmed tissues were placed in a cryomold, containing a irop of Tissue Tek. The surfaces to be cut into sections were raced down. The whole sections were then covered with Tissue Tek, and the mold frozen in a dry ice - methanol slurry. The sample prepared that way was ready for cutting into $20 \mathrm{\mu m}$ sections when completely frozen.

The sections were placed onto $7.3 \mathrm{\mu m}$ Kapton support $\mathrm{rilm}$ mounted in a cardboard $5 \mathrm{~cm} \times 5 \mathrm{~cm}$ slide mount. The adjacent sections were taken and used ror histochemical purposes and for the ldentification of the structures and regions analyzed.

\section{EXPERIMENTAL ARRANGEMENT}

A white photon beam from the National Synchrotron Light Source of effective energy range upto $30 \mathrm{keV}$ was used is this study. The experiment was performed at $x-26 C$ beam line. The beam is delivered through a vacuum beam pipe and the slze of the beam is defined by four tantalum slits of $160 \mathrm{\mu m}$ thick.

The apertured beam passes through a hellum filled Ion Chamber which provides a normalization of the X-ray spectra to the number 
or incident photons. The chacarteristic X-rays produced detected with a SicLil detector with an energy resolution of 15. $\mathrm{eV}$ for an ${ }^{55} \mathrm{Fe}$ source for $\mathrm{x}-\mathrm{ray}$ of the $5 . \dot{9} \mathrm{keV}$. In order to minimize the background in the spectra the detector was placed at $90^{\circ}$ to the beam in the plane of the electron orbit. Samples were mounted at $45^{\circ}$ to the beam on a stepping driver $X$. Y. Z, $\odot$ stage. During the measurement sample was observed through a IV camera mounted on the microscope. Fig. $Z$ shows a diagram or an $X$-2bC apparatus.

All samples were irradlated in the same experimental conditions for $300 \mathrm{~s} l i f e$ time. After selecting experimental conditions [5] the filters were established to be $100 \mathrm{\mu m}$ thick Aluminum foll for a beam and $150 \mathrm{\mu m}$ thick Kapton foll for the detector. The beam size was $100 \mu \mathrm{m} \times 100 \mu \mathrm{m}$ for both the point analysis and the two-dimensional semi-quantitative mapping. Fig. 3 shows a typlcal spectrum of a rat cerebelium section.

\section{RESULTS}

The concentrations of a total number of 11 elements CCa. Mn. $\mathrm{Fe}, \mathrm{Cu}, \mathrm{Zn}$. Se, $\mathrm{Br}, \mathrm{Rb}, \mathrm{Sr}, \mathrm{Pb}$, and $\mathrm{Hgl}$ were determined. Those elements were studied in three structures of the sample: Molecular Cell Layer (MCL), Inner Granule Cell Layer (IGL), and FIber Tract CFT.

In order to obtain an average value of the element concentration each structure was measured in three dirferent points. Fig. 4 shows the graphs of the average values of TE concentrations in three different structures for two diets and the average concentration in the whole tissues an appropriate label for a diet. Table 2 shows the average values of the TE concentrations for the whole anlmal section.

The map of iron distribution in one of the samples is shown in fig. 5 as an example of a two-dimensional seniquantitative mapping. The composed figure also shows a photograph of an analyzed section. The lighter plxels correspond to higher iron concentration. 


\section{DISCUSSI ON AND CONCLUSI ONS}

From tables 1 and 2 one can easily notlce. that 1 ncreased TE concentrations of $\mathrm{Ca}, \mathrm{Mn}, \mathrm{Cu}$, and $\mathrm{Zn}$, for Purlina diet correspond to increased concentrations of those elements in the diet itself. Such a correlation seems to be normal and was expected.

Al though the $\mathrm{Fe}$ concentration in the Purina diet is higher than in that the AIN diet there is no signiflcant difference between the average concentrations of this element in the samples.

The case of Se proofs different. Increased Se concentration in the diet resulted in decreased concentration of $1 \mathrm{t}$ in the sample. This was not expected and needs rurther study. There must be some biological interactions between elements responsible for that phenomena.

As for the other elements analyzed but not present in those diets. One can see that the $P b$ concentration in the samples for the Purina diet is higher than that for the AIN dlel. while for Hg the relation is opposite.

Br concentration for the AIN diet is lower than that for the Purina diet. There is no significant difference between $\mathrm{Sr}$ and $\mathrm{Rb}$ concentrations for those two diets.

A more detalled study may explain the origin of significant difference for mean values. Table 3 shows the result of the Student $t$-test on mean values for the structures and whole sections. The comparison was made between the same structure types. The diference between the mean values were regarded significant with $a=0.05$.

An interesting case is the strontium structural distribution for two diets. Although there is no significant diference between the mean values for the whole section there are signiflcant difrerences for the structures. The Sr concentration in FT-structure for the AIM diet is higher than in FT- ror the Purina diet while Sr concentration in MGL-structure for the AIN diet is lower than in MGL- for the Purina diet. There is no significant difference between $S r$ concentration in IGL structure for both diets. Therefore, the mean values for the sections are not different. This case seems very interesting and needs further study. 
The graphs in fig. 4 show the distribution of the $T E$ in each structure. It is obvious that the diet has significant influance to TE distribution in the cerebelium. The calculated correlations for each structure for both diets confirm that significance.

The potassium analysis would be important due to biological significance of this element but it was not possible to perform any quantitative or quolitative analysis of potassium because of the experimantal setup. All the samples were kept in the air during the measurements and that caused an appearance of an Ar peak in the spectrum which invalidated the potassium analysis.

The correlation coefficients were tested with a test of significance assuming a significant level $\alpha=0.1$. Comparing the structures between themself one can observe some lnteresting dependences. For diet A the following correelations has been round. A strong positive correlation is observed between Ca and Zn for FI and IGL while for MCL that correlation is rather negative. For all three structures a positive correlation is observed between $\mathrm{Fe}$ and $\mathrm{Br}$. The correlation between $\mathrm{Cu}$ and $\mathrm{Zn} i \mathrm{~s}$ positive only for IGL but for FT is rather negative. The same relation 15 observed for: $\mathrm{Ca}$ and $\mathrm{Cu}, \mathrm{Fe}$ and $\mathrm{Zn}$, and $\mathrm{Ca}$ and $\mathrm{Fe}$.

For diet $P$ the other elements are signiflcantly correlated than those for diet A. For all three structures a positive correlation is observed between: $\mathrm{Cu}$ and $\mathrm{Zn}, \mathrm{Br}$ and $\mathrm{Ca}$, and $\mathrm{Rb}$ and Se. $\mathrm{Also}$ positively correlates $\mathrm{Pb}$ and $\mathrm{Cu}$. $A$ negative correlation is observed between $Z n$ and $M n$ for FT while for IGL it is positive. $Z_{n}$ and $C a$ show a positive correlation for IGL and MCL but for FT they shoy rather negative correlation. Also the negative correlation $1 \mathrm{~s}$ observed between $\mathrm{Zn}$ and $\mathrm{Fe}$ for $\mathrm{FT}$ and $\mathrm{MCL}$. For IGL there is a positive correlation between $Z n$ and $M n$. Tab. 4 sumarize the results of the test.

From the above observations one can conclude that the concentration level of TE in a structure depends on the structure itself that means 1 t depends on the runction of a structure. Comparing tables 1 and 31 is obvious that diet and the concentration level of $\mathrm{TE}$ in the diet have significant influences on the TE distribution in the brain. It has also been found that the increased concentration of some element in the diet does not have to result of 1 ts increasing in analyzed tissue. Such a fact 
was observed in case of Se. 


\section{REFERENCES}

1. J. R. Prohaska, Physiological Reviews Vol.67 3 (1987) 858

2. G. V. I yengar, W. E. Kollmer, H. J. M. Browen, Ed. Dr. Hans F. Ebel Verlag Chemie, Weinheim - New York 1978

3. Report of the American Inst. of Nutrition, Journal of Nutrition $107(2)$ (1987) 1340

4. Formulab Chow 5008. Ralston Purina Co. Catalog P. 17

5. W. M. Kwiatek. A. L. Hanson, and K. W. Jones. "Selection of the Experimental Conditions for White Light SRIXE Measurements" NIM (to be published). 
FIGURE CAPTIONS

Fig. 1. Illustration of a rat cerebellum section.

Fig. 2. Diagram of an $X$-eEC apparatus.

Fig. 3. Typical SRIXE spectrum of a rat cerebellum section.

Fig. 4. Graphs of the average values of TE concentration in three different structures for two diets and the average concerntraction in the whole tissue.

Fig. 5. Composed picture of a rat cerebellum section photograph and semi-quantitative two-dimensional mapping.

$-9-$ 


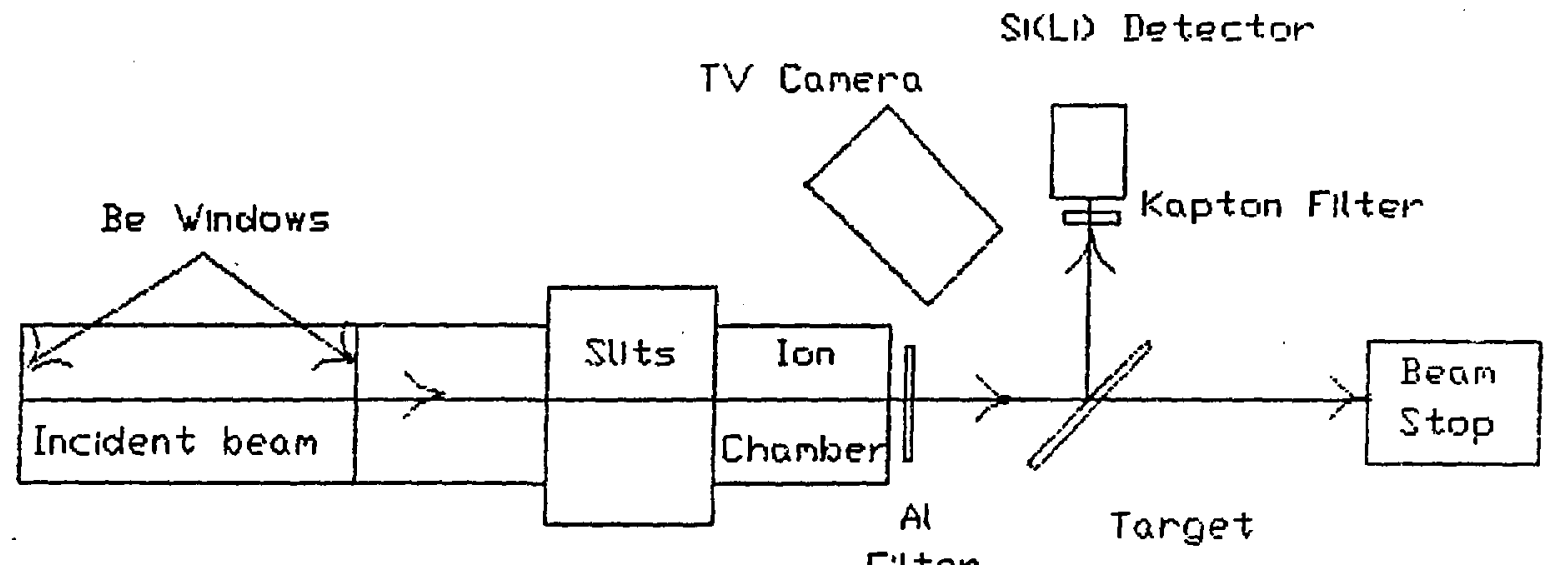

Filter

Schematic Diagram of $X-26$ XRF Beam Line 


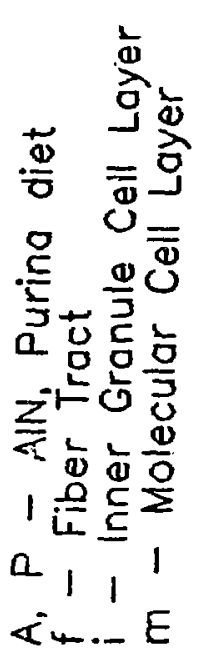

ตั

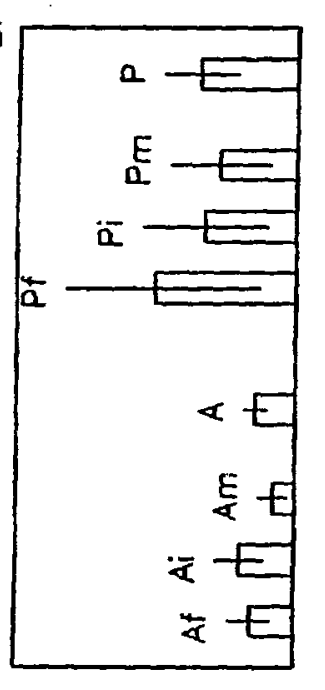

a

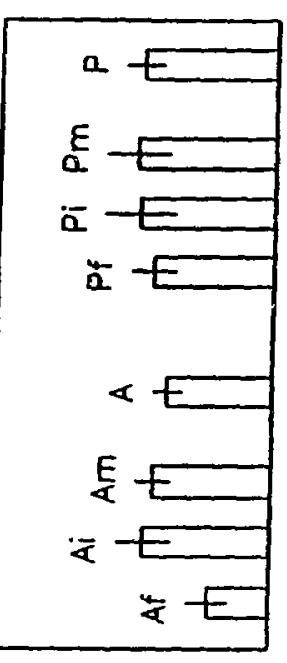

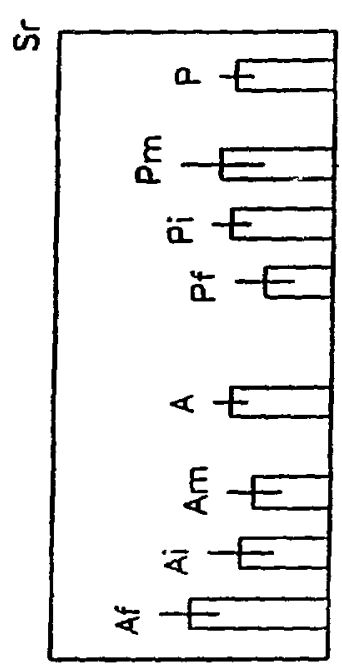

ํㅜ

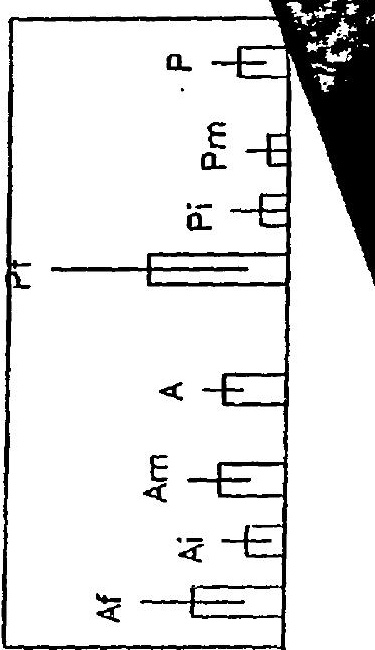

모

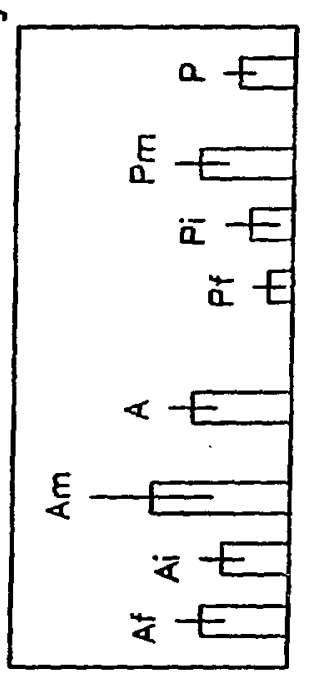

ह
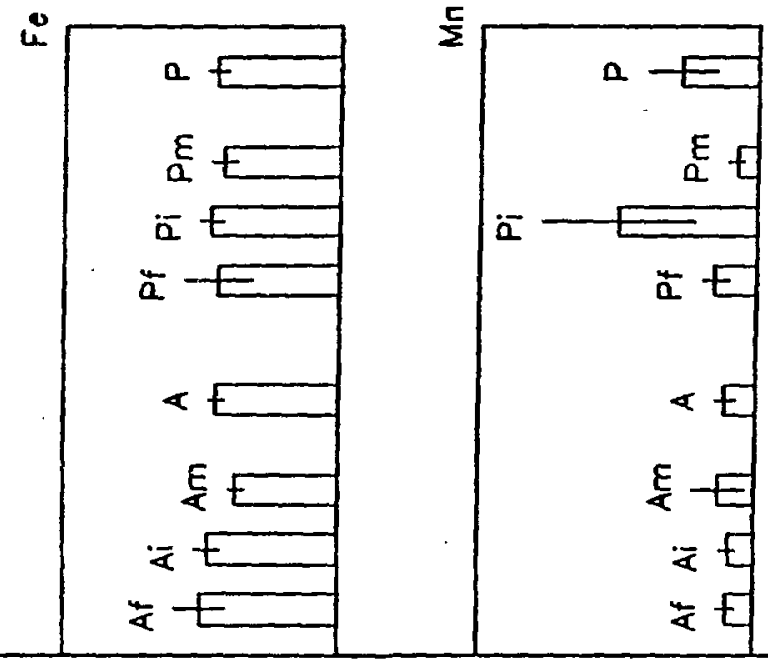

E

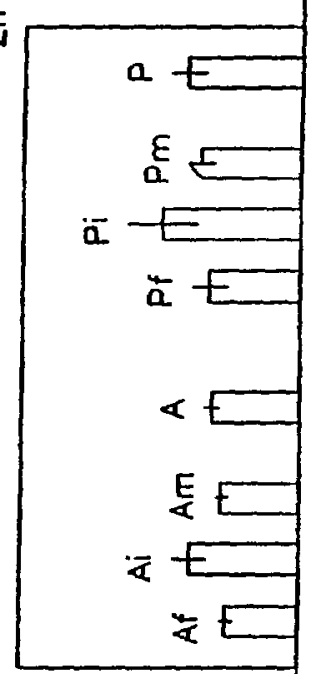

¿

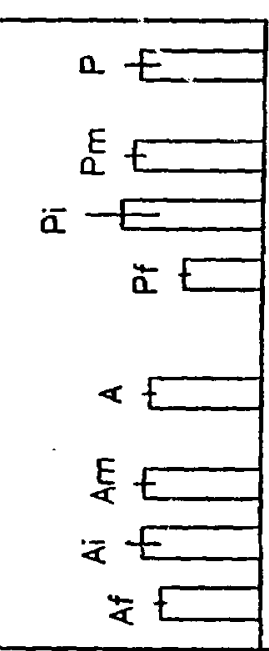

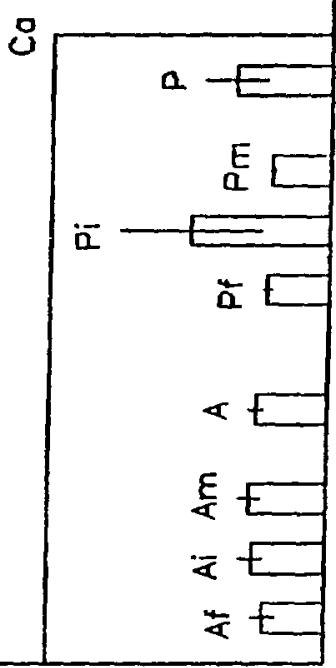



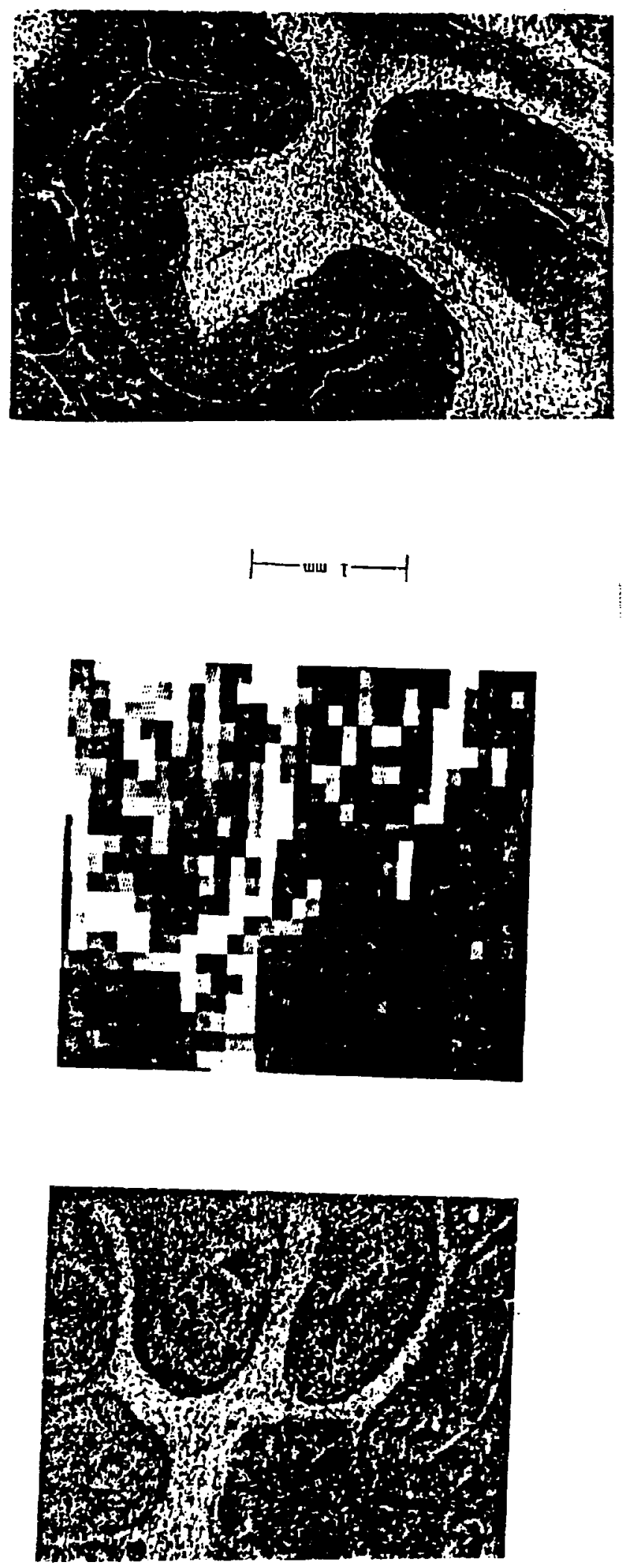
frable 1. Comparison of elemental composition of $A I N-7 B^{T M}$ and purina diets

\begin{tabular}{|c|c|c|}
\hline Ingredi ent & $A I N-76^{T M}$ & Pur ina \\
\hline $\mathrm{Ca}$ & $0.52 \%$ & $1.0 \%$ \\
\hline $\mathbf{P}$ & $0.40 \%$ & $0.65 \%$ \\
\hline K & $0.36 \%$ & $1.1 \%$ \\
\hline $\mathrm{Mg}$ & $0.05 \%$ & $0.2 \%$ \\
\hline $\mathrm{Na}$ & $0.10 \%$ & $0.28 \%$ \\
\hline $\mathrm{Cl}$ & $0.156 \%$ & $0.48 \%$ \\
\hline$F$ & --- & $30.0 \mathrm{ppm}$ \\
\hline $\mathbf{F e}$ & 35.0 Ppm & $200.0 \mathrm{ppm}$ \\
\hline $\mathrm{Zn}$ & $30.0 \mathrm{ppm}$ & 73. $3 \mathrm{ppm}$ \\
\hline $\mathrm{Mn}$ & $54.0 \mathrm{ppm}$ & $70.7 \mathrm{ppm}$ \\
\hline Cu & 6. $0 \mathrm{ppm}$ & $16.0 \mathrm{ppm}$ \\
\hline Co & --- & 0.4 ppm \\
\hline$I$ & 0.2 ppm & $0.8 \mathrm{ppm}$ \\
\hline $\mathrm{Cr}$ & 2. 0 ppm & $1.4 \mathrm{ppm}$ \\
\hline Se & $0.1 \mathrm{ppm}$ & $0.2 \mathrm{ppm}$ \\
\hline Sulfate & $0.1 \%$ & --- \\
\hline
\end{tabular}


Table a. Average TE concentrations for the whole anlmal sectlon for two dlets: Cvalues are in ppm

\begin{tabular}{|c|c|c|c|c|c|}
\hline & AIN & Purla & & AIN & Purisa \\
\hline $\mathrm{Ca}$ & $\begin{array}{l}35.5 \\
\pm 3.3\end{array}$ & $\begin{array}{r}46.8 \\
\pm 15.5\end{array}$ & Se & $\begin{array}{r}0.42 \\
\pm 0.11\end{array}$ & $\begin{array}{r}0.20 \\
\pm 0.07\end{array}$ \\
\hline Mn & $\begin{array}{r}0.3 \\
\pm 0.1\end{array}$ & $\begin{array}{r}0.7 \\
\pm 0.3\end{array}$ & $\mathrm{Br}$ & $\begin{array}{r}0.13 \\
\pm 0.04\end{array}$ & $\begin{array}{r}0.32 \\
\pm 0.12\end{array}$ \\
\hline $\mathrm{Fe}$ & $\begin{array}{l}16.3 \\
\pm 1.2\end{array}$ & $\begin{array}{l}16.2 \\
\pm 1.3\end{array}$ & $\mathbf{R b}$ & $\begin{array}{r}0.19 \\
\pm 0.06\end{array}$ & $\begin{array}{r}0.15 \\
\pm 0.08\end{array}$ \\
\hline Cu & $\begin{array}{r}1.8 \\
\pm 0.1\end{array}$ & $\begin{array}{r}2.0 \\
\pm 0.3\end{array}$ & Sr & $\begin{array}{r}0.83 \\
\pm 0.14\end{array}$ & $\begin{array}{r}0.82 \\
\pm 0.14\end{array}$ \\
\hline $\mathrm{Zn}$ & $\begin{array}{r}9.4 \\
\pm 0.8\end{array}$ & $\begin{array}{l}12.3 \\
\pm 1.8\end{array}$ & $\mathrm{~Pb}$ & $\begin{array}{r}2.0 \\
\pm 0.3\end{array}$ & $\begin{array}{r}2.5 \\
\pm 0.4\end{array}$ \\
\hline & & & $\mathrm{Hg}$ & $\begin{array}{r}1.0 \\
\pm 0.2\end{array}$ & $\begin{array}{r}0.6 \\
\pm 0.2\end{array}$ \\
\hline
\end{tabular}




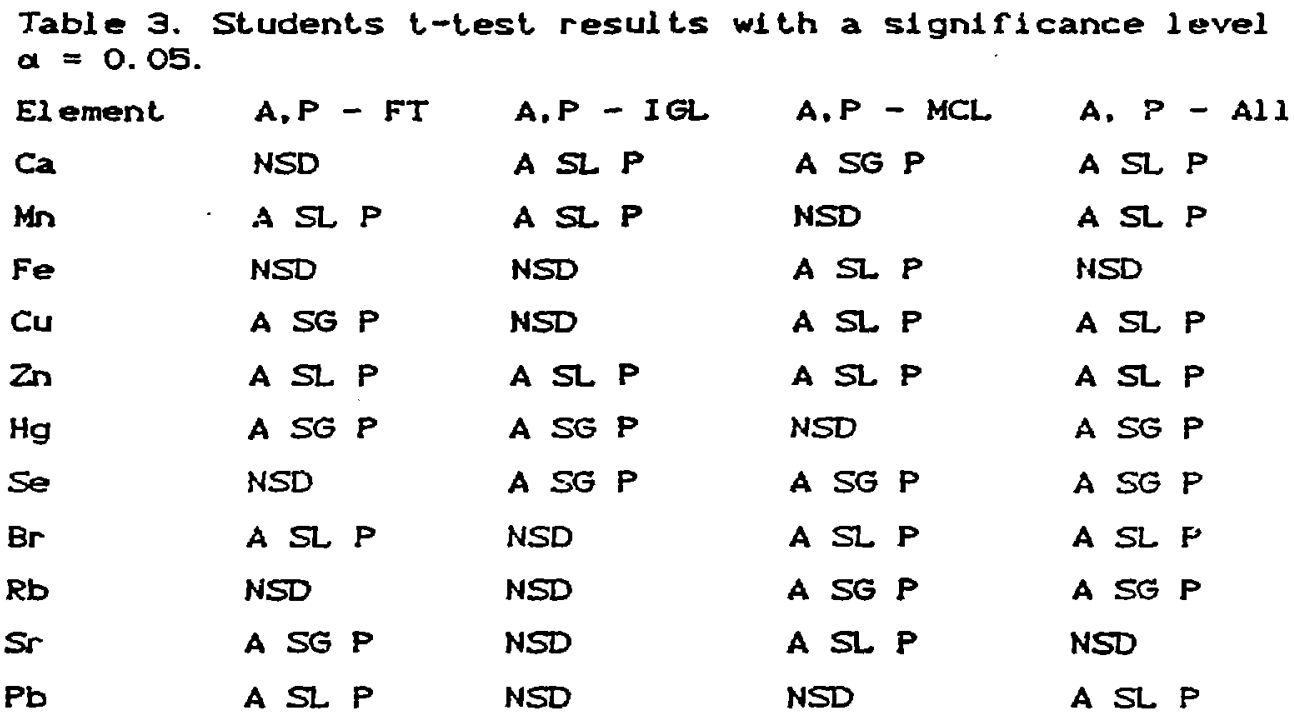

where: A - mean for the AIN diet.

P - mean for the Purina diet.

st - significantly less (than).

SG - significantly greather (than).

NSD - no significant difference. 
Table 4. List of signiflcantly correlated elements.

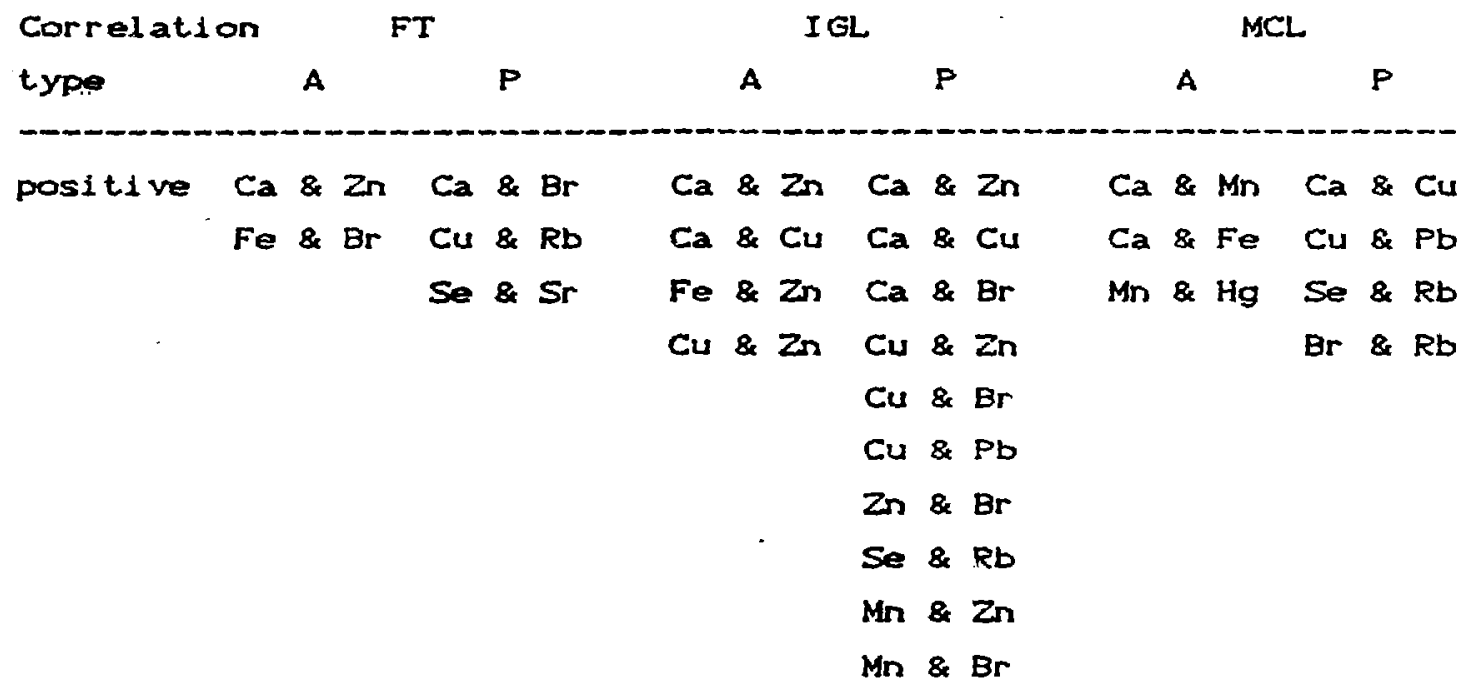

negative $\mathrm{Cu}$ \& $\mathrm{Mn} \mathrm{Cu}$ \& $\mathrm{Mn}$

Cu \& $\mathrm{Hg} \mathrm{Mn} \& \mathrm{Rb}$

Se $8 \mathrm{~Pb}$ 